\title{
Armenia, Azerbejdżan, Gruzja. Kaukaz Południowy na rozdrożu?
}

Charakterystyczną cechą Kaukazu Południowego jest wielość narodów, Cetnosów, społeczności i kultur funkcjonujących na niewielkiej przestrzeni geograficznej, co z jednej strony stanowi o bogactwie regionu, a z drugiej staje się niekiedy czynnikiem konfliktogennym. Czynniki te wpływają na politykę wewnętrzną Armenii, Azerbejdżanu i Gruzji oraz stanowią wyzwanie w szerszym kontekście międzynarodowym. Tąpnięcia wewnętrzne, na płaszczyźnie etnicznej widoczne głównie w Armenii i Gruzji, a na politycznej ${ }^{1}$ czy społecznej ${ }^{2}$ - w Azerbejdżanie, stanowią pierwszy wymiar rozdrożnego charakteru Kaukazu Południowego, którym to słowem obrazowo określiliśmy jego specyfikę.

Wymiar drugi to pomostowy charakter regionu, zarówno w płaszczyźnie wertykalnej, jak i horyzontalnej. Przedmiotowy obszar zakotwiczony jest między łańcuchem Kaukazu i Bliskim Wschodem, a z pozostałych stron ograniczają go Morze Czarne i Morze Kaspijskie. Na płaszczyźnie horyzontalnej wiąże się to przede wszystkim z potencjałem stworzenia szlaków komunikacyjnych pomiędzy oboma akwenami, a na płaszczyźnie wertykalnej - głównie z buforowym statusem całego obszaru, zakotwiczonego pomiędzy różnymi modelami cywilizacyjnymi i ośrodkami siły. Kaukaz Południowy ma w związku z tym olbrzymie znaczenie geopolityczne, głównie w wymiarach ekonomicznym (surowcowym) i geostrategicznym.

1 Zob. artykuł Barbary Patlewicz w tym numerze.

2 S. E. Cornell, Azerbaijan since independence, Routledge, 2011, s. 262-264. 
O rozdrożnym charakterze regionu świadczy też wreszcie orientowanie się położonych tam państw na różne centra polityczne. Gruzja zwraca się ku kolektywnie rozumianemu Zachodowi, Azerbejdżan stawia na partnerskie relacje z Turcją ${ }^{3}$ a Armenia ciąży ku Federacji Rosyjskiej. Dużą rolę odgrywają tam również Stany Zjednoczone, Chiny i Iran. Stwarza to różnym aktorom zewnętrznym (często antagonistycznie nastawionym względem siebie) możliwość ingerowania w sprawy regionu i instrumentalizowania toczących się tam sporów wewnętrznych i międzypaństwowych.

W Armenii, Azerbejdżanie i Gruzji obserwujemy obecnie głębokie przeobrażenia wewnątrzpolityczne, a zaostrzenie w lipcu 2020 r. konfliktu w Górskim Karabachu utrwaliło przekonanie o niestabilności Kaukazu Południowego i udowodniło, że ma on niebagatelne znaczenie dla różnych aktorów stosunków międzynarodowych. Złożoność problemów, z którymi zmaga się ten obszar, doskonale wyraża stosowana wobec niego przez szereg autorów metafora węzła gordyjskiego ${ }^{4}$.

Odpowiadając na potrzebę naukowego wyjaśniania tak zarysowanych zagadnień, przedstawiamy uwadze Czytelników nowy numer „Spraw Międzynarodowych", przygotowany wysiłkiem około dwudziestu analityków zajmujących się przedmiotowym regionem.

Otwierają go rozmowy z Radosławem Sikorskim i Ekaterine Tkeszelaszwili, będące w naszym zamyśle dokumentacją procesów decyzyjnych i percepcji kluczowych dla regionu wydarzeń, które rozgrywały się około roku 2008. Skupiliśmy się w nich przede wszystkim na inicjatywie Partnerstwa Wschodniego, szczycie NATO w Bukareszcie i wojnie rosyjsko-gruzińskiej. Następnie prezentujemy ankietę redakcyjną, w której zaproszeni badacze przedstawili swoją ocenę sytuacji międzynarodowej na Kaukazie Południowym. Pozostając w obszarze tej problematyki i ankietowego pytania o miejsce regionu $\mathrm{w}$ polityce wschodniej państwa polskiego, w pierwszym bloku tematycznym przedstawiamy artykuły Wojciecha Materskiego i Pawła Kowala związane z jej najbardziej

3 Turkish-Azerbaijani relations. One nation - two states?, ed. M. Ismayilov, N. A. Graham, Routledge, London-New York 2016.

4 W. Górecki, Kaukaski węzeł gordyjski. Konflikt o Górski Karabach, Ośrodek Studiów Wschodnich, Warszawa 2020 (Raport OSW); K. Oskanian, Fear, weakness and power in the post-Soviet South Caucasus. A theoretical and empirical analysis, Palgrave Macmillan, 2013. 
aktywnym kierunkiem - gruzińskim. Czytelnik znajdzie w nich analizę specyfiki i dynamiki relacji polsko-gruzińskich w różnych okresach historycznych. W dwóch kolejnych blokach znalazły się teksty dotyczące zewnętrznego oddziaływania na Kaukaz Południowy i wewnętrznych uwarunkowań regionu, pokazujące konieczność spojrzenia na jego sprawy z obu tych przenikających się i wzajemnie warunkujących perspektyw. W pierwszym zamieściliśmy artykuły Bartłomieja Krzysztana, Nurłana Alijewa i Jarosława Stróżyka, a w drugim - Barbary Patlewicz i Renaty Król-Mazur oraz artykuł recenzyjny Andrzeja Furiera. Artykuły Katarzyny Kosowskiej i Justyny Misiągiewicz tworzą natomiast blok dotyczący pozamilitarnych wymiarów bezpieczeństwa Azerbejdżanu, którego stabilność ekonomiczna i potencjał surowcowy mają niebagatelne znaczenie dla architektury systemu międzynarodowego w regionie. Numer zamykają opracowane przez Karola Przywarę materiały źródłowe ukazujące modelowy przykład nawiązywania i utrzymywania relacji międzynarodowych na poziomie regionalnym przez władze Dolnego Śląska i Adżarii.

$\mathrm{Na}$ zakończenie chcielibyśmy wyrazić wdzięczność wszystkim Recenzentom za niezwykle wnikliwe i cenne uwagi, które przyczyniły się do podniesienia jakości tego numeru.

Jakub Bornio Pawet Kowal 